Agrisaintifika

Jurnal Ilmu-Ilmu Pertanian

Vol. 2, No. 1, 2018

\title{
Efektivitas Dosis Pupuk Bokasi Pada Fase Vegetatif Tanaman Sambiloto (Andrographis paniculata Ness)
}

\author{
Sudarmi $^{1}$, Wartini $^{2}$ \\ ${ }^{1}$ Program Studi Agribisnis Fakultas Pertanian Univet Bantara Sukoharjo \\ ${ }^{2}$ Fakultas Kesehatan Masyarakat Univet Bantara Sukoharjo \\ JI. Letjen S. Humardani No. 1 Sukoharjo, kode pos 57512, Telp. (0271) 593156, Fax (0271) 591065, \\ Corresponding author Phone: 082136724147 E-mail: Sudarmi1959@yahoo.com
}

\begin{abstract}
ABSTRAK
Pertumbuhan tanaman sangat dipengaruhi oleh kandungan unsur hara tanah. Tujuan penelitian ini untuk mengetahui dosis pupuk bokashi yang tepat agar mendapatkan pertumbuhan terbaik dari tanaman sambiloto (Andrographis paniculata Ness). Metode penelitian adalah eksperimen, dirancang dengan Rancangan Acak Kelompok Lengkap (RAKL), dengan perlakuan tunggal yaitu variasi dosis pupuk bokashi dengan 3 ulangan. Variasi dosis pupuk bokashi ada 4 level yaitu : Tanpa dipupuk bokashi $\left(\mathrm{B}_{1}\right)$ sebagai pembanding; Pupuk bokashi 5 ton/ha $\left(\mathrm{B}_{2}\right)$; Pupuk bokashi 10 ton/ha $\left(\mathrm{B}_{3}\right)$; Pupuk bokashi 15 ton/ha $\left(\mathrm{B}_{4}\right)$. Hasil penelitian Dosis pupuk bokashi berpengaruh terhadap tinggi tanaman, jumlah cabang dan jumlah daun. Kesimpulan dosis 15 ton/ha pupuk bokashi menunjukkan pertumbuhan yang paling optimal hasil rata-rata meliputi : tinggi tanaman $60,07 \mathrm{~cm} / \operatorname{tanaman}$, jumlah cabang 24,11 buah/tanaman dan jumlah daun 121,33 buah/tanaman berbeda nyata dengan tanpa pupuk bokashi sebagai kontrol.
\end{abstract}

Kata Kunci : Dosis, Pupuk bokashi, Pertumbuhan, Sambiloto

\begin{abstract}
Plant growth is strongly influenced by soil nutrient content. The purpose of this research is to know the correct dosage of bokashi fertilizer in order to get the best growth from the bitter plant (Andrographis paniculata Ness). The experimental method is an experiment, designed with Randomized Complete Block Design (RAKL), with a single treatment that is variation dose of bokashi fertilizer with 3 replications. Variation of a dose of fertilizer bokashi there is 4 level that is: Without fertilized bokashi (B1) as a comparison; 5 ton/ha (B2) bokashi fertilizer; Bokashi fertilizer 10 ton/ha (B3); Bokashi fertilizer 15 ton/ha (B4). The result of research Dose of bokashi fertilizer influence to plant height, number of branch and number of a leaf. Conclusion dose 15 ton/ha of bokashi fertilizer showed the most optimum growth of average yield include: plant height $60,07 \mathrm{~cm} /$ plant, number of branches 24,11 fruit/plant and number of leaf 121,33 fruit/plant significantly different with no fertilizer bokashi as a control.
\end{abstract}

Keywords: Dosage, Bokashi Fertilizer, Growth, Sambiloto

\section{PENDAHULUAN}

Sambiloto (Andrographis paniculata Ness) merupakan salah satu dari sembilan obat tradisional yang diunggulkan untuk dikaji sampai tahap uji klinis (Widyawati, 2007). Menurut WHO, sekitar $65 \%$ dari penduduk Negara maju dan $80 \%$ dari penduduk Negara berkembang telah menggunakan obat herbal sebagai obat tradisional. Obat tradisional merupakan bagian dari kekayaan leluhur bangsa Indonesia yang sampai sekarang masih dilestarikan dengan budaya minum jamu, maka perlu ditingkatkan kualitasnya sehingga dapat menjadi obat alternatif disamping obat modern (Sobandrio et.al, 1996). Sampai saat ini tanaman sambiloto belum dibudidayakan (tumbuh liar), masyarakat petani mengumpulkan dari habitat di sekitarnya menyebabkan mutu simplisianya rendah karena bercampur dengan tanaman lain (Sudarmi dan Nikentari, 2011). Pembudidayaan sambiloto merupakan salah satu cara untuk memperbaiki kuantitas dan kualitas simplisia sehingga memenuhi tuntutan kebutuhan (Kartosapoetro,1992). 
Pemupukan untuk tanaman obat dianjurkan berasal dari pupuk alami (organik) supaya tidak timbul residu yang berefek farmakologis (Winarto, 2003). Penggunaan pupuk kimia (anorganik) memang mampu memberikan respon yang lebih cepat terhadap pertumbuhan dan hasil, tetapi penggunaan yang terus menerus dalam jangka panjang justru menurunkan kesuburan/produktivitas tanah dan memperbesar kepekaan tanaman terhadap penyakit (Sugito dkk. 1995; Lingga dan Marsono, 2002). Sedang pupuk organik dapat memperbaiki sifat fisik dan kimia tanah, memempunyai kandungan unsur hara lebih lengkap baik unsur hara makro maupun mikro (Sudarmi, 2011; Gustia 2009), walaupun cara kerja pupuk organik lebih lambat dibanding pupuk kimia.

Upaya mengatasi permasalan yang ditimbulkan oleh pengaruh negative diatas, sudah ada teknologi tepat guna yang aman bagi kelangsungan kesuburan tanah di kemudian hari yaitu dengan menggunakan teknologi Effective Microorganisms-4 (EM-4). Hasil fermentasi bahan organik dengan inokulasi EM-4 ini, disebut "Bokashi" yang kemudian digunakan sebagai pupuk organik (Yuliandari, 2008). Bokasi merupakan pupuk organik yang siap pakai dan dalam waktu singkat dapat menyuburkan tanah serta meningkatkan pertumbuhan dan produksi tanaman (Gustia, 2009) Larutan EM4 sebagai dekomposernya terdiri dari mikroorganisme yang diisolasi secara khusus untuk menguraikan sampah organik dengan cepat, sehingga dapat menurunkan $\mathrm{C} / \mathrm{N}$ ratio bahan organik (Sudarmi, 2011; Djunaedy, 2009). Mikroorganisme yang terkandung dalam EM4 terdiri dari bakteri fotosintesis, bakteri asam laktat (Lactobacillus sp), Actinomycetes dan ragi (Wijoseno, 1998; Sutrisari, 2013).

Bahan untuk pembuatan bokashi dapat diperoleh dengan mudah di sekitar lahan pertanian, seperti: pupuk kandang, jerami, rumput, sisa-sisa tanaman kacangan, sekam atau serbuk gergaji. Pembuatan bokashi ini sangat didukung banyaknya limbah bahan organik seperti : jerami, sekam dan pupuk kandang di daerah penelitian yang belum maksimal pengolahannya dan dapat mencegah terjadinya pencemaran lingkungan (Anonim, 2014; Niswati, dkk., 2013).

Berdasar latar belakang di atas, masih diperlukan untuk meneliti tentang pengaruh dosis pupuk bokashi terhadap pertumbuhan tanaman sambiloto (Andrographis paniculata Ness). Penelitian ini bertujuan untuk mengetahui dosis pupuk bokashi yang tepat agar mendapatkan pertumbuhan terbaik tanaman sambiloto (Andrographis paniculata Ness).

\section{BAHAN DAN METODE}

Penelitian ini dilaksanakan mulai bulan April sampai September 2017 di Kebun Kelurahan Gayan Kecamatan Sukoharjo Kabupaten Sukoharjo, dengan ketinggian tempat $100 \mathrm{~m}$ dpl dan Laboratorium Universitas Veteran Bangun Nusantara Sukoharjo.

Alat yang digunakan : pot pembibitan $\varnothing 10$ $\mathrm{cm}$; pot penanaman $\varnothing 30 \mathrm{~cm}$; selang plastic; ember; cangkul; sabit; gunting pangkas, kantong plastic; alat ukur ( timbangan anlitik; timbangan kapasitas $10 \mathrm{~kg}$; rol meter; penggaris) dan alat tulis.

Bahan yang digunakan : benih sambiloto, bokashi kotoran kambing, bokashi kotoran sapi, bokasi kotoran ayam, insektisida dan fungisida herbal, tanah gromosol di tempat penelitian sebagi media tanam.

Rancangan Percobaan: Berupa eksperimen yang disusun dalam rancangan acak kelompok lengkap (RAKL) dengan perlakuan tunggal yaitu dosis pupuk bokashi dengan 3 ulangan. Variasi dosis pupuk bokashi, terdiri dari 4 level yaitu :

$$
\begin{aligned}
& \mathrm{B}_{1}=\text { tanpa bokashi }(0 \text { bokashi }) ; \\
& \mathrm{B}_{2}=\text { bokashi } 5 \text { ton/ha }(50 \mathrm{gr} / \mathrm{tanaman}) \\
& \mathrm{B}_{3}=\text { bokashi } 10 \text { ton } / \text { ha }(100 \mathrm{gr} / \mathrm{tanaman}) ; \\
& \mathrm{B}_{4}=\text { bokashi } 15 \text { ton/ha }(150 \mathrm{gr} / \text { tanaman })
\end{aligned}
$$

Tiap perlakuan dibuat 10 tanaman, sehingga seluruhnya diperlukan $4 \times 3 \times 10=120$ tanaman.

Variabel yang diamati meliputi : panjang/tinggi tanaman, jumlah cabang, dan jumlah daun tanaman sambiloto.

Analisis data : data dianalisis dengan metode analisis ragam (Anova) apabila 
Agrisaintifika

perlakukan menunjukkan pengaruh nyata diuji lanjut dengan uji perbandingan rata-rata Duncan Multiple Range Test (DMRT) pada jenjang murad $\alpha=0,05$ (Christensen, 1996).

\section{HASIL DAN PEMBAHASAN}

Pertumbuhan sambiloto dipengaruhi oleh faktor lingkungan seperti kandungan unsur hara tanah, radiasi matahari, curah hujan, adanya gangguan hama penyakit dan lain-lain. Tanaman sambiloto yang dimanfaatkan adalah bagian vegetatif tanaman yaitu berupa batang, cabang dan daun yang telah dikeringkan lebih popular disebut simplisia sambiloto. Indikator pertumbuhan pada vase vegetative sambiloto yang diamati meliputi tinggi tanaman, jumlah cabang dan jumlah daun, Berdasar hasil analisis ragam, perlakuan dosis pupuk bokashi berpengaruh nyata terhadap semua indikator pertumbuhan, Pada Tabel 1. disajikan indikator pertumbuhan pada perlakuan dosis pupuk bokashi.

Berdasar hasil pengamatan pada Tabel 1 , diketahui bahwa dosis 15 ton/ha pupuk bokashi menunjukkan pertumbuhan yang paling optimal, dengan rata-rata tinggi tanaman 60,07 $\mathrm{cm} /$ tanaman, rata-rata jumlah cabang 24,11 buah/tanam dan rata-rata jumlah daun 121,33 buah/tanaman berbeda nyata dengan tanpa pupuk bokashi sebagai kontrol.

Pada dosis lain yang lebih rendah, efektifitas bokashi juga terlihat lebih rendah namun masih menunjukan berbeda nyata dengan kontrol. Berdasar hasil analisis indikator pertumbuhan bahwa tanah gromosol di tempat penelitian memiliki unsur hara terbatas, sehingga kurang mampu mendukung pertumbuhan tanaman sambiloto pada tingkat optimal. Menurut Higa dan Wididana (1993), bokasi selain mengandung unsur hara N P K dan unsur mikro lainnya juga mengandung mikroorganisme aktif untuk proses fermentasi dan dekomposisi. Oleh sebab itu semakin banyak bokasi yang diberikan ke tanaman akan menunjukkan respon yang baik untuk mendukung tanaman secara optimal.

Pada Gambar 1. berdasarkan histogram tinggi tanaman pada fase vegetatif sambiloto menunjukkan bahwa perlakuan dosis pupuk bokashi mulai tampak pengaruhnya pada pengamatan minggu ke 6 (berumur 2 bulan). Pada minggu ke 2 dan minggu ke 4 pertumbuhan tinggi tanaman belum menunjukkan perbedaan yang signifikan, hal ini karena tanaman masih muda sehingga belum memiliki perakaran yang sempurna, akhirnya akar belum bisa menyerap unsur hara dengan optimal. Sesuai dengan pendapat Berger (1962) dalam Yulistrarini (1991) bahwa tanaman muda menyerap unsur hara dalam jumlah sedikit, sejalan dengan pertumbuhan tanaman yang akhirnya penyerapan unsur hara akan meningkat. Untuk melakukan pertumbuhan vegetatif tanaman sangat membutuhkan unsur $\mathrm{N}$, hal inilah yang kurang dari kontrol (tanpa diberi pupuk bokashi). Tanah yang diberi pupuk bokashi akan ada penambahan unsur hara yang ada dalam pupuk bokashi dan ini tidak didapatkan oleh kontrol. Kotoran ternak yang merupakan bahan dasar pupuk bokashi memiliki kandungan $\mathrm{N}$ total $1,853 \%$ untuk kotoran ayam; $1,437 \%$ untuk kotoran kambing dan 1,648\% untuk kotoran sapi (Sudarmi, 2016). Perlakuan dosis pupuk bokashi 15 ton/ha memberikan pertumbuhan tinggi tanaman paling baik dibanding pelakuan 10 ton/ha maupun 5 ton/ha, bahkan hasil paling rendah adalah kontrol (0 ton/ha). Hal ini karena semakin banyak dosis pupuk bokashi yang diberikan, maka unsur $\mathrm{N}$ yang terkandung di dalam pupuk bokashi juga semakin banyak yang diterima oleh tanah. Unsur $\mathrm{N}$ ini sangat penting untuk pertumbuhan tanaman karena $\mathrm{N}$ berfungsi sebagai penyusun asam-asam amino, protein, komponen pigmen klorofil yang penting dalam proses fotosintesis. Sebaliknya jika tanaman kekurangan $N$ menyebabkan pertumbuhan dan perkembangan terganggu dan hasil menurun yang disebabkan oleh terganggunya pembentukan khlorofil yang sangat penting untuk proses fotosintesis (Sholeh dkk, 1997).

\section{KESIMPULAN}

Dosis pupuk bokashi berpengaruh pada tinggi tanaman, jumlah cabang, jumlah daun tanaman. Dosis pupuk bokashi terbaik adalah 15 ton ha/ha menghasilkan rata-rata tinggi 
tanaman $60,07 \mathrm{~cm}$, jumlah cabang 24,11 buah dan jumlah daun 121,33 buah berbeda nyata dengan tanpa pupuk bokashi sebagai kontrol.

\section{UCAPAN TERIMAKASIH}

Terima kasih kepada Koordinator Perguruan Tinggi Swasta Wilayah VI Kementerian RISTEK DIKTI Sesuai Surat Perjanjian Penugasan Pelaksanaan Program Riset Terapan Tahun Anggaran $2017 \quad$ Nomor :014/K6/KM/SP2H/RISET TERAPAN/2016.

\section{DAFTAR PUSTAKA}

Anonim, 2014. Pengertian Bokashi. http://www.caragampang.com/2014/08/p engertian-bokashi- bahan-organikkaya.html. Diakses 15 Maret 2015.

Christensen, R. 1996. Analysis of variance, Design and Regression : Applied Statistical Methods. Chapman and Hall. London.

Djunaedy, A., 2009. Pengaruh Jenis dan Dosis Pupuk Bokashi terhadap Pertumbuhan dan Hasil Kacang Panjang (Vigna sinensis L.). Jurnal Agrovigor 2 (1) : 4246 (Pustaka jurnal)

Gustia, H. 2009. Pengaruh Pemberian Bokashi Terhadap Pertumbuhan dan Produksi Tanaman Cabe Varietas Inko-99. Akta Agrosia 12 (2):113-123.

Higa, T. and G.N. Wididana. 1994. Effective Microorganisme : Dimensi Baru dalam Kyusei Nature Farming. Majalah Tumbuh 1 (94) : 39-14

Lingga dan Marsono, 2002. Petunjuk Penggunaan Pupuk. Panebar Swadaya. Jakarta.

Niswanti; Retni, W.; Irmasari. 2013. Pengaruh Pemberian Berbagai Dosis Bokashi terhadap Pertumbuhan Semai Kemiri (Aleurites moluccana L.). Jurnal Warta Rimba 1(1): 1-8

Sholeh, Nursyamsi, D. Adiningsih, S.J. 1997. Pengelolaan Bahan Organik dan Nitrogen untuk Tanaman Padi dan Ketela Pohon pada Lahan Kering yang Mempunyai Tanah Ultisol di Lampung.
Prosiding Pertemuan Pembahasan dan Komunikasi Hasil Penelitian Tanah dan Agroklimat, Bidang Kimia dan Biologi Tanah Departemen Pertanian. Hal 193206.

Sudarmi, 2016. Perlakuan Variasi Pupuk Kandang Pengaruhnya Terhadap Mutu Bokashi. Jurnal Magistra 98 (XXVIII) :46-51.

, 2011. IbM Kelompok Tani Pembuatan Pupuk Organik Dari Limbah Jerami di Kelurahan Begajah Kecamatan/Kabupaten Sukoharjo. Proceeding Seminar Hasil Penelitian dan Pengabdian Kepada Masyarakat. LPPM Universitas Veteran Bangun Nusantara Sukoharjo. 26 Februari-2011. ISBN : 978-602-99009-0-3 Hal. 105-110.

dan Intan Nikentari, 2011. Kajian Dosis Pupuk NPK dan Macam Media Terhadap Pertumbuhan dan Hasil Sambiloto (Andrographis paniculata Ness). Proceeding Seminar Hasil Penelitian dan Pengabdian Kepada Masyarakat. 7 Desember 2011. LPPM Universitas Veteran Bangun Nusantara Sukoharjo. ISBN: 978- 602-99172-53.Halaman 30-37.

Sugito, Y., Yulia, N., dan Ellis, N. 1995. Sistem Pertanian Organik. Fakultas Pertanian Universitas Brawijaya Malang.

Sutrisari, S.N. 2013. Efective Microorganisme4.http://sutrisarisabrinanainggolan.blogs pot.co.id/2013/06/effectivemicroorganisme-4-em4-normal-0.html. Diakses 02 Maret 2015.

Tola, dkk. 2007. Pengaruh Penggunaan Pupuk Bokashi Kotoran Sapi Terhadap Pertumbuhan dan Produksi Tanaman Jagung. Agrisistem, 3 (1):11-19 Juni 2007.

Wijoseno, A. H. 1998. Pengaruh Dosis Dan Waktu Aplikasi Bokashi Terhadap Pertumbuhan Dan Hasil Strawberry (Fragaria vesca L) http://em4indonesia.com/pengaruh-dosis-danwaktu-aplikasi-bokashi-terhadappertumbuhan-dan-hasil-tanaman- 
Agrisaintifika

Jurnal Ilmu-Ilmu Pertanian

Vol. 2, No. 1, 2018

Sudarmi \& Wartini. 2018

strawberry-fragaria-vesca-I. Diakses 5 Maret 2015.

Yulistrarini, 1991. Pengaruh Jarak Tanam dan Pemupukan Urea Terhadap

Yuliandari, 2008. Pembuatan dan Manfaat Pupuk Bokashi. https://wyuliandari.wordpress.com/2008/ 09/24/pembuatan-dan-manfaat-pupukorganik-bokhasi/ Diakses 05 Februari Pertumbuhan dan Hasil Tanaman Jagung Sayur (Zea mays L). skripsi. Fakultas Pertanian Universitas Brawijaya Malang. 2015

Tabel 1. Rerata Tinggi Tanaman, Jumlah Cabang Dan Jumlah Daun Sambiloto Pada Perlakuan Dosis Pupuk Bokashi, Musim Tanam 2017.

\begin{tabular}{|c|c|c|c|}
\hline Perlakuan & $\begin{array}{c}\text { Tinggi } \\
\text { tanaman }(\mathrm{cm})\end{array}$ & $\begin{array}{c}\text { Jumlah cabang } \\
\text { (buah) }\end{array}$ & $\begin{array}{c}\text { Jumlah daun } \\
\text { (buah) }\end{array}$ \\
\hline B1 (tanpa bokashi) & $48,67 \mathrm{a}$ & $19,11 \mathrm{a}$ & $80,50 a$ \\
\hline $\begin{array}{c}\text { B2 (bokashi } 5 \\
\text { ton/ha) }\end{array}$ & $54,06 \mathrm{~b}$ & $20,56 a$ & $96,79 \mathrm{~b}$ \\
\hline $\begin{array}{c}\text { B3 (bokashi } 10 \\
\text { ton/ha) }\end{array}$ & $57,58 \mathrm{bc}$ & $21,58 a b$ & $106,33 \mathrm{bc}$ \\
\hline $\begin{array}{c}\text { B4 (bokasi } 15 \\
\text { ton/ha) }\end{array}$ & $60,07 \mathrm{c}$ & $24,11 b$ & $121,33 \mathrm{c}$ \\
\hline
\end{tabular}

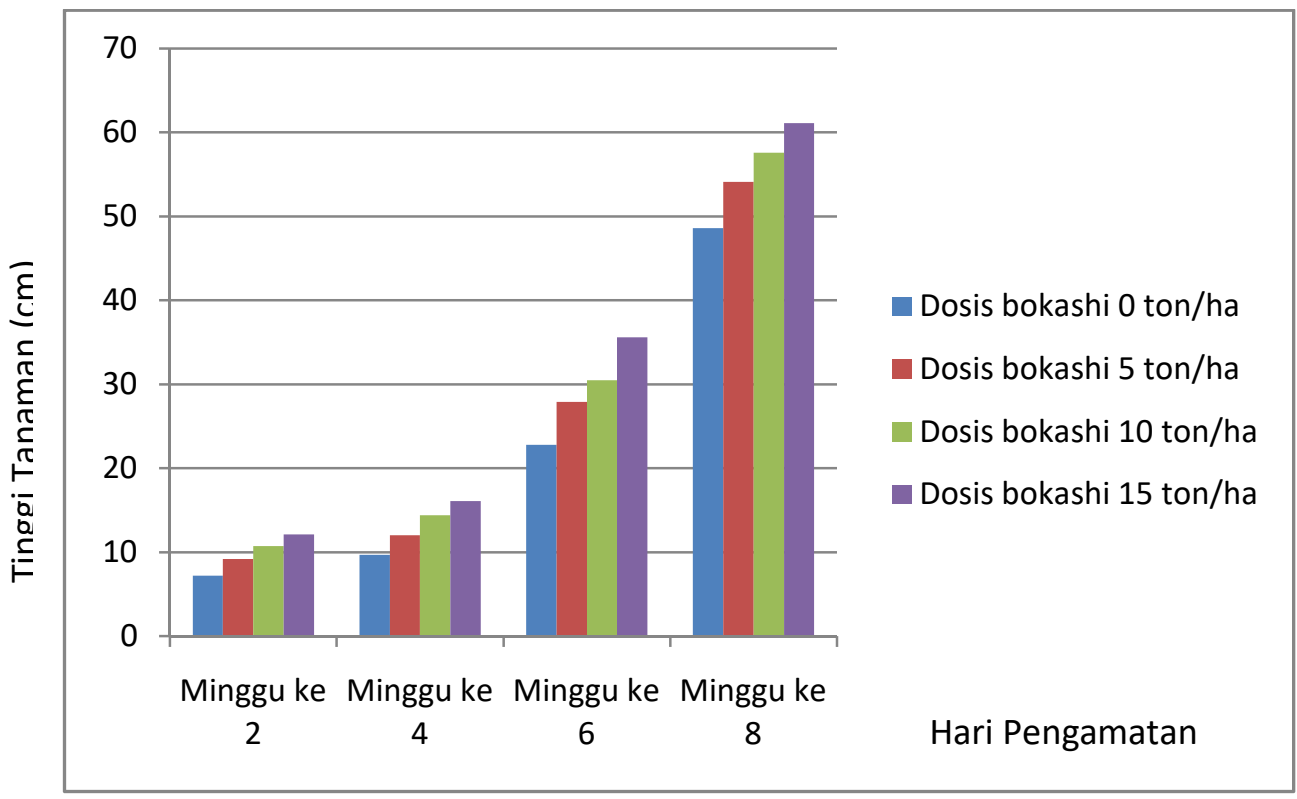

Gambar 1. Histogram Tinggi Tanaman Pada Fase Vegetatif Sambiloto 